\title{
Desorption and Re-Adsorption of Procion Red MX-5B Dye on Alumina-Activated Carbon Composite
}

\author{
Fatma, Poedji Loekitowati Hariani ${ }^{\star}$, Fahma Riyanti, and Wiwin Sepriani \\ Department of Chemistry, Faculty of Mathematics and Natural Sciences, Sriwijaya University, \\ Jl. Palembang-Prabumulih km 32, Ogan Ilir 30662, Indonesia
}

Received April 12, 2017; Accepted January 22, 2018

\begin{abstract}
The alumina-activated carbon has the ability to adsorb and desorb the procion red MX-5B. The research evaluated the influence of desorption agent, contact time, and temperature on desorption process of procion red $\mathrm{MX}$ $5 B$ dye with alumina-activated carbon composite and the adsorption capacity of the composite after desorption process. The desorption agents used in desorption process were solution with $\mathrm{pH} 2-10, \mathrm{H}_{2} \mathrm{O}_{2} 30 \%(\mathrm{~V} / \mathrm{V})$, methanol $70 \%(\mathrm{~V} / \mathrm{V})$ and ethanol $70 \%(\mathrm{~V} / \mathrm{v})$. The variation of contact time was in the range from 30 to 270 min and the temperature was set between $30-75{ }^{\circ} \mathrm{C}$. The result concluded that the highest desorption efficiency up to $98.56 \%$ was achieved using ethanol $70 \%(\mathrm{~V} / \mathrm{v})$ for $240 \mathrm{~min}$ at $45{ }^{\circ} \mathrm{C}$. The desorption kinetic followed the pseudo-first-order with the release constant $\left(k_{d e s}\right)$ of $6.56 \times 10^{-2} \mathrm{~min}^{-1}$. The SEM micrograph showed there is a more porous surface on the composite after the desorption compared to before the desorption. The EDX analysis indicated that alumina content in the composite was reduced after desorption process. FTIR spectra of the composite before and after desorption process showed a peak of Al-O at 592 and $590 \mathrm{~cm}^{-1}$ which was proved that alumina still exists in the composite after the desorption process. The alumina-activated carbon composite was re-used to adsorb procion red $M X-5 B$ dye. After three times of desorption and re-adsorption process, the capacity adsorption was decreased from 12.38 to $7.38 \mathrm{mg} / \mathrm{g}$.
\end{abstract}

Keywords: alumina-activated carbon composite; procion red MX-5B dye; desorption, adsorption

ABSTRAK

Komposit alumina-karbon aktif mempunyai kemampuan mengadsorpsi dan mendesorpsi zat warna procion merah MX-5B. Penelitian ini mempelajari pengaruh reagen pendesorpsi, waktu kontak, dan suhu pada proses desorpsi zat warna procion merah MX-5B dari komposit alumina-karbon aktif dan kemampuan adsorpsi komposit alumina-karbon aktif setelah proses desorpsi. Reagen pendesorpsi yang digunakan pada proses desorpsi meliputi larutan dengan $\mathrm{pH}$ pada interval 2-10, $\mathrm{H}_{2} \mathrm{O}_{2} 30 \%(\mathrm{~V} / \mathrm{v})$, metanol $70 \%(\mathrm{v} / \mathrm{V})$ dan etanol $70 \%(\mathrm{~V} / \mathrm{v})$. Variasi waktu kontak pada rentang 30-270 menit dan suhu antara 30-75 ${ }^{\circ} \mathrm{C}$. Hasil penelitian menunjukkan bahwa efektivitas desorpsi terbesar diperoleh ketika menggunakan etanol pada waktu 240 menit dan temperatur $45{ }^{\circ} \mathrm{C}$ yakni sebesar 98,56\%. Kinetika desorpsi mengikuti pseudo orde-satu dengan konstanta desorpsi ( $k_{\text {des }}$ ) sebesar 6,56 $\times 10^{-2} \mathrm{~min}^{-1}$. Hasil analisis morfologi menggunakan SEM menunjukkan bahwa pori-pori pada permukaan komposit setelah desorpsi lebih banyak dibandingkan sebelum proses desorpsi. Hasil EDS menunjukkan berkurangnya kandungan alumina pada komposit setelah proses desorpsi. Spektra FTIR komposit sebelum dan setelah desorpsi menunjukkan adanya serapan yang sama yaitu serapan Al-O yang muncul pada bilangan gelombang 592 dan 590 $\mathrm{cm}^{-1}$. Hal ini menunjukkan masih adanya alumina pada komposit setelah proses desorpsi. Komposit alumina-karbon aktif mengalami penurunan daya serap terhadap zat warna procion merah $M X-5 B$ setelah proses desorpsi sebanyak 3 kali yaitu dari 12,38 menjadi $7,38 \mathrm{mg} / \mathrm{g}$.

Kata Kunci: komposit alumina-karbon aktif; zat warna procion merah MX-5B; desorpsi, adsorpsi

\section{INTRODUCTION}

Synthetic dye is often used as coloring agent in the textile industry. The effluent dye discharged into the environment can be a contaminant for surface water and groundwater [1]. Procion red MX-5B dye has a formula of $\mathrm{C}_{19} \mathrm{H}_{10} \mathrm{Cl}_{2} \mathrm{~N}_{6} \mathrm{Na}_{2} \mathrm{O}_{7} \mathrm{~S}_{2}$ with molecular weight of

* Corresponding author

Email address : pujilukitowati@yahoo.com
$615.33400 \mathrm{~g} / \mathrm{mol}$ [2]. Several methods have been studied to reduce synthetic dye contained in wastewater such as photocatalytic, chemical oxidation and adsorption [2-4]. Adsorption is considered as the most effective method to reduce dyes contaminated in textile industrial wastewater [5]. Adsorption has several advantages such as relatively low-cost, easy and

Fatma et al. 
simple to be carried out, and provide high sorption efficiency [6].

The study of desorption is conducted to assess the adsorption process and indicate the adsorption stability [1]. The dye can be released from the adsorbent which have saturated by dye. The adsorbent can be re-used to adsorb the dye. Desorption and regeneration of adsorbent could decrease the processing cost [7-8]. Generally, adsorbent regeneration was conducted using various solvents. The desorption process can be done using organic and inorganic solvents. Commonly used desorption agents in this process are methanol, ethanol, isopropanol, acid and base solution, $\mathrm{NaCl}, \mathrm{HNO}_{3}$, Fenton, and $\mathrm{H}_{2} \mathrm{O}_{2}$ which depend on the type of adsorbate and adsorbent. Other studies stated that temperature process and contact time also affect the desorption efficiency [9-12].

Activated carbon is the most widely used adsorbent in the adsorption process. The adsorption capacity of activated carbon can be increased by modification of its surface using metal oxide [13]. The metal oxides which can be composited with activated carbon to increase adsorption capacities are $\mathrm{Fe}_{3} \mathrm{O}_{4}, \mathrm{CuFe}_{2} \mathrm{O}_{4}, \mathrm{MnFe}_{2} \mathrm{O}_{4}$, $\mathrm{SiO}_{2}, \mathrm{TiO}_{2}$, and $\mathrm{Al}_{2} \mathrm{O}_{3}$. Alumina $\left(\mathrm{Al}_{2} \mathrm{O}_{3}\right)$ is considered as one of metal oxide with several advantages, i.e., good mechanical property and thermal stability [14]. Alumina is also known to have pore system and active sites on its surface. Alumina was reported by several researchers for having the ability to adsorb orange G, yellow monochlorotriazine, and yellow dichlorotriazinecolor black G [5,15-16]. Surface modification of adsorbent using alumina was expected to increase the adsorption capacity as shown by modification of bentonite-alumina [17], alumina-chitosan [18], and activated carbonalumina [19-20].

Modified alumina with activated carbon as an alumina-activated carbon composite can be used to adsorb procion red MX-5B dye. The adsorption process followed the pseudo-first order reaction and well fitted to Langmuir isotherm models [19]. In this research, we evaluated the desorption efficiency of alumina-activated carbon composite and the re-adsorption of procion red MX-5B dye after desorption process. In this study, the evaluated parameters of desorption process were various desorption agents, contact time and temperature. The pseudo-first-order kinetic model was applied to describe the kinetic desorption process.

\section{EXPERIMENTAL SECTION}

\section{Materials}

In this experiment, all chemicals used were of reagent grade and used without further purification. $\mathrm{Al}\left(\mathrm{NO}_{3}\right)_{3}, \mathrm{NaOH}, \mathrm{HCl}, \mathrm{H}_{2} \mathrm{O}_{2}$, and $\mathrm{NH}_{4} \mathrm{OH}$ were purchased<smiles></smiles>

Fig 1. Chemical structure of procion red MX-5B

from Merck whereas procion red MX-5B was obtained from Sigma-Aldrich, distilled water, Whatman filter paper 42. The chemical structure of procion red MX-5B dye presented at Fig. 1.

\section{Instrumentation}

The instrument used for the preparation of alumina-activated carbon composite, adsorption and desorption process were oven, hot plate, $\mathrm{pH}$-meter Hanna HI 8424, incubator shaker Stuart SI500, furnace Naber 2804, UV-Visible spectrophotometer Shimadzu mini 1240. Characterization of the composite was analyzed by Scanning Electron Microscopy-Energy Dispersive X-Ray Spectroscopy (SEM-EDX) JEOL JSM 6510 and Fourier Transform Infrared (FTIR) Shimadzu 8400 .

\section{Procedure}

Preparation of alumina-activated carbon composite Activated carbon was made from Gelam wood. The preparation of activated carbon was following procedure reported in the previous article [19]. Characteristic of activated carbon has surface area 535 $\mathrm{m}^{2} / \mathrm{g}$ and pore volume of $0.56 \mathrm{~cm}^{3} / \mathrm{g}$. Synthesis of activated carbon-alumina composite (percentage of alumina is $20 \%$ ) was conducted by a co-precipitation method using $\mathrm{Al}\left(\mathrm{NO}_{3}\right)_{3}$ and $\mathrm{NH}_{4} \mathrm{OH}$ as precursors. $\mathrm{A}$ solution of $200 \mathrm{~mL}$ of $0.1 \mathrm{~N} \mathrm{Al}\left(\mathrm{NO}_{3}\right)_{3}$ was added to $50 \mathrm{~g}$ of activated carbon. The mixture was stirred at $120 \mathrm{rpm}$ using a magnetic stirrer while $1 \mathrm{~N} \mathrm{NH}_{4} \mathrm{OH}$ is added gradually until $\mathrm{pH}$ reached \pm 10 . The reaction between $\mathrm{Al}\left(\mathrm{NO}_{3}\right)_{3}$ and $\mathrm{NH}_{4} \mathrm{OH}$ produce an amorphous $\mathrm{Al}(\mathrm{OH})_{3}$. Furthermore, the precipitate obtained was washed using distilled water and calcined at $350{ }^{\circ} \mathrm{C}$ for $3 \mathrm{~h}$. The calcination process produces alumina $\left(\mathrm{Al}_{2} \mathrm{O}_{3}\right)$ from the dehydroxylation of $\mathrm{Al}(\mathrm{OH})_{3}$. 


\section{Adsorption experiment}

Adsorption was carried out in batch method. In a typical process, $50 \mathrm{~mL}$ of procion red $\mathrm{MX}-5 \mathrm{~B}$ dye with a concentration of $30 \mathrm{mg} / \mathrm{L}$ was added with $0.15 \mathrm{~g}$ alumina-activated carbon composite and shook for 2 hours at $150 \mathrm{rpm}$ at room temperature. The suspension was filtered and the filtrate was analyzed using UVVisible spectrophotometer at $542 \mathrm{~nm}$ [17]. The amount of dye adsorbed was following eq.1.

$$
\mathrm{q}_{\mathrm{e}}=\frac{\mathrm{V}}{\mathrm{m}}\left(\mathrm{C}_{\mathrm{o}}-\mathrm{C}_{\mathrm{e}}\right)
$$

where $q_{e}, C_{0}$, and $C_{e}$ are the amount of procion red $M X-$ $5 \mathrm{~B}$ dye adsorbed onto composite $(\mathrm{mg} / \mathrm{g})$, the initial concentration of dye $(\mathrm{mg} / \mathrm{L})$, concentration of dye at equilibrium ( $\mathrm{mg} / \mathrm{L})$, respectively. Besides that, $\mathrm{V}$ and $\mathrm{m}$ are the volume of the solution $(\mathrm{L})$ and the weight of the composite $(\mathrm{g})$. The study was carried out by the following process: alumina-activated carbon composite adsorption, desorption process and re-adsorption. Eq. 2 describes the amounts of dye remaining on the adsorbent as a function of time.

$\mathrm{q}_{\mathrm{t}}=\mathrm{q}_{\mathrm{e}}-\mathrm{C}_{\mathrm{t}}(\mathrm{v} / \mathrm{m})$

where $q_{t}$ is the amount of dye remaining on the absorbent $(\mathrm{mg} / \mathrm{g})$ and $C_{t}$ is the concentration of dye $(\mathrm{mg} / \mathrm{L})$ in the solution.

\section{Desorption and re-adsorption process}

The alumina-activated carbon composite which has adsorbed procion red MX-5B was desorbed by several desorption agents. Desorption process using $0.1 \mathrm{~g}$ of adsorbent added by $10 \mathrm{~mL}$ solution with $\mathrm{pH}$ in the range from 2-10 (adjusted by adding $\mathrm{HCl}$ and $\mathrm{NaOH} 1 \mathrm{M}$ ), methanol $70 \%(\mathrm{v} / \mathrm{v})$, ethanol $70 \%(\mathrm{v} / \mathrm{v})$, and $\mathrm{H}_{2} \mathrm{O}_{2} 30 \%$ $(\mathrm{v} / \mathrm{v})$. The mixture was stirred using a shaker for $3 \mathrm{~h}$ at room temperature. Then, the suspension was filtered. The concentration of filtrate was carried out using UVVisible spectrophotometer at $542 \mathrm{~nm}$. The procedure of desorption was also performed for various contact time (30-240 $\mathrm{min}$ ) and temperature $\left(30,45,60\right.$, and $\left.75^{\circ} \mathrm{C}\right)$. Morphology analysis and elemental content of the composite before and after desorption were analyzed using SEM-EDX and the functional group was recorded by FTIR.

The kinetics of desorption study was obtained by pseudo first-order reaction [22-23]. The solvent used for desorption of procion red $\mathrm{MX}-5 \mathrm{~B}$ dye is the best solvent. Composite used for all process were re-used in the readsorption process following the same procedure of adsorption [19]. Desorption and re-adsorption process was repeated three times to measure the desorption efficiency.

\section{RESULT AND DISCUSSION}

\section{Effect of Desorption Agents}

Desorption of procion red $\mathrm{MX}-5 \mathrm{~B}$ dye from alumina-activated carbon composite using solution at a various $\mathrm{pH}$ of $2-10$, methanol, ethanol, and $\mathrm{H}_{2} \mathrm{O}_{2}$ are shown in Table 1. The higher $\mathrm{pH}$ of the solution shows more efficiency in desorption of procion red $M X-5 B$ dye. The surface properties of alumina and the functional groups on the adsorbent are affected by $\mathrm{pH}$ solution [12,15,24]. The alumina has a point of zero charge $\left(\mathrm{pH}_{\mathrm{pzc}}\right)$ of 7.4 . In solution with $\mathrm{pH}>\mathrm{pH}_{\mathrm{pzc}}$, alumina would have negative charge $[11,15,25]$. Thus, in alkaline solution, there is electrostatic repulsion between anion of dye with the negatively charged of the surface of alumina [15]. In this study, the effect of $\mathrm{pH}$ to increase the desorption efficiency was insignificant. The desorption efficiency at $\mathrm{pH} 2$ was $1.28 \%$ while at $\mathrm{pH} 10$ was $3.01 \%$.

Desorption using $\mathrm{H}_{2} \mathrm{O}_{2} 30 \%$ solution gives the desorption efficiency of $1.24 \%$. The desorption mechanism using $\mathrm{H}_{2} \mathrm{O}_{2} 30 \%$ solution is oxidation reaction [26]. $\mathrm{H}_{2} \mathrm{O}_{2}$ released free radical of hydroxyl which will reacted with a dye compound [27]. The catalyst, such as metal ions, is needed to initiate the process. In this study, desorption process did not use catalyst that caused the slow rate of free radical

Table 1. Desorption of procion red $M X-5 B$ dye from alumina-activated carbon composite

\begin{tabular}{lcc}
\hline $\begin{array}{c}\text { Desorption } \\
\text { agent }\end{array}$ & $\begin{array}{c}\text { Conc. desorbed } \\
\left(\mathrm{mg} \mathrm{L}^{-1}\right)\end{array}$ & $\begin{array}{c}\text { Desorption } \\
\text { efficiency }(\%)\end{array}$ \\
\hline $\mathrm{pH} 2$ & 0.327 & 1.28 \\
$\mathrm{pH} 3$ & 0.308 & 1.30 \\
$\mathrm{pH} 4$ & 0.327 & 1.34 \\
$\mathrm{pH} 5$ & 0.346 & 1.42 \\
$\mathrm{pH} 6$ & 0.404 & 1.64 \\
$\mathrm{pH} 7$ & 0.500 & 2.08 \\
$\mathrm{pH} 8$ & 0.635 & 2.45 \\
$\mathrm{pH} 9$ & 0.769 & 3.07 \\
$\mathrm{pH} \mathrm{10}$ & 0.750 & 3.01 \\
$\mathrm{Ethanol} \mathrm{70 \%}$ & 22.404 & 92.31 \\
$\mathrm{Methanol} \mathrm{70 \%}$ & 16.827 & 73.10 \\
$\mathrm{H}_{2} \mathrm{O}_{2} 30 \%$ & 0.327 & 1.24 \\
\hline
\end{tabular}
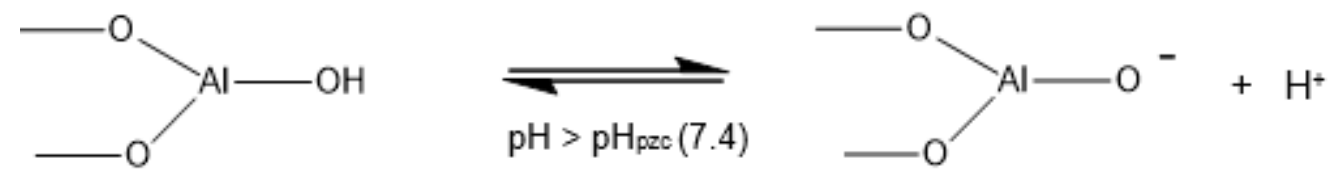

Fig 2. Structure of alumina at $\mathrm{pH}$ solution $>\mathrm{pH}_{\mathrm{pzc}}$

Fatma et al. 


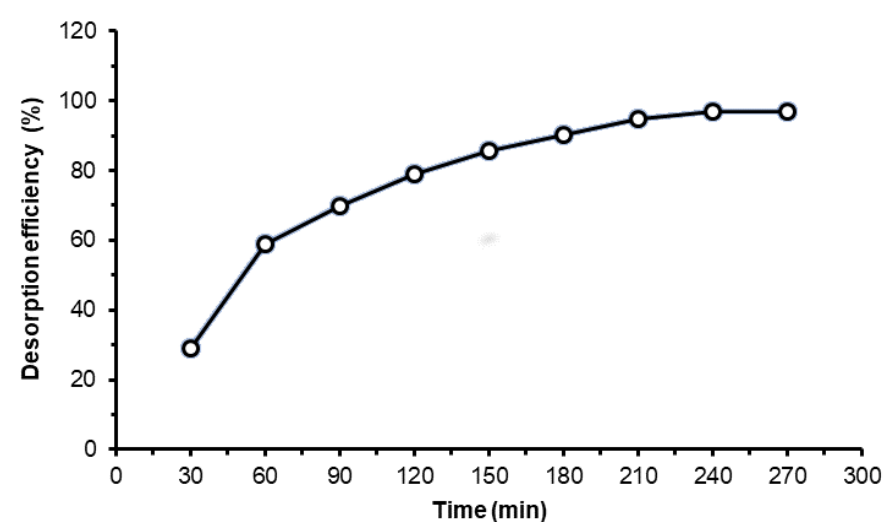

Fig 3. Effect of contact time to procion red MX-B58 dyes desorption from alumina-activated carbon composite (weight of adsorbent $0.1 \mathrm{~g}, \mathrm{pH}$ solution of 6.3 , volume of ethanol $10 \mathrm{~mL}$ at room temperature $\pm 30^{\circ} \mathrm{C}$ )

formation. Another reference shows $\mathrm{H}_{2} \mathrm{O}_{2}$ cannot be used as a solvent for desorption of remazol yellow dye from zeolite [24].

Desorption is affected by the availability of hydroxyl group, molecular weight, and desorbing agent hydrophobicity. The dye is more soluble in the alcohol than water due to the forming of hydrogen bond between hydroxyl groups in alcohol with the dye. The organic solvent has higher desorption efficiency than inorganic solvent [11]. The data are given in Table 1, indicates that alcohol gives higher desorption efficiency than the other solvents. Methanol and ethanol have one hydroxyl group with partition coefficient $\left(\mathrm{K}_{\mathrm{ow}}\right)$ of methanol and ethanol are 0.15 and 0.48 , respectively. A solvent with high $\mathrm{K}_{\mathrm{ow}}$ $\left(K_{\text {ow }}>1\right)$ is more hydrophobic. The dyes compound will compete with hydrophobic groups of ethanol or methanol to be bonded to the adsorbent. If hydrophobicity of solvent is high, it will attach procion red MX-5B dye more strongly $[9,11]$.

In this study, the desorption efficiency of methanol and ethanol are 73.10 and $92.31 \%$, respectively (Table $1)$. The desorption efficiency is also influenced by the molecular weight [11]. Ethanol has a greater molecular weight than methanol. Thus methanol is more polar than ethanol. The dye itself is classified into organic compounds which have polar and non polar groups. However, the dye tends to be non-polar, so the dye is more soluble in ethanol than methanol.

\section{Effect of Contact Time to Desorption Process}

The procion red dye MX-5B desorption from alumina-activated composite was conducted using ethanol at various contact time in the range of $30-240$ min. The desorption of dye at different time intervals in order to get the equilibrium time was achieved. The

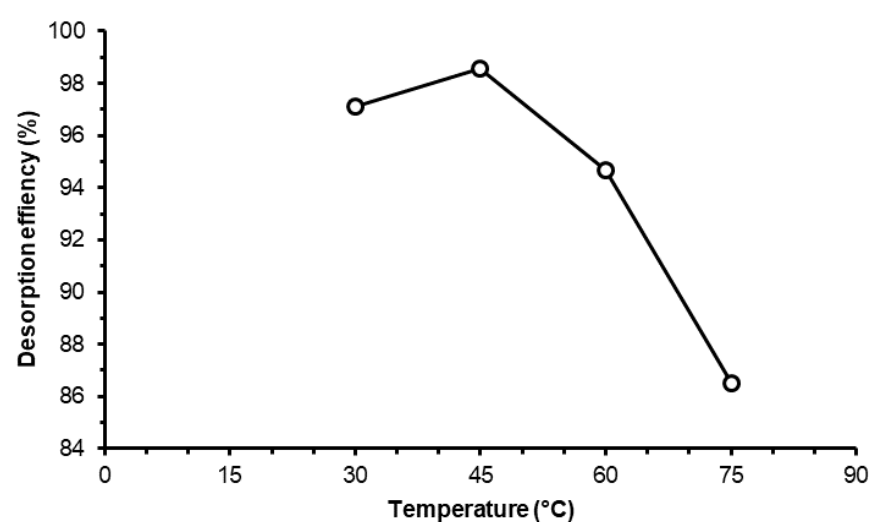

Fig 4. Effect of temperature to procion red MX-B58 dye desorption from alumina-activated carbon composite (weight of adsorbent $0.1 \mathrm{~g}, \mathrm{pH}$ solution of 6.3 , volume of ethanol $10 \mathrm{~mL}$ and contact time $240 \mathrm{~min}$ )

effect of contact time on the amount of dyes desorbed at room temperature $\left( \pm 30^{\circ} \mathrm{C}\right)$ and $\mathrm{pH}$ of solution 6.3 is shown in Fig. 3. From the figure obtained the longer contact time increased the amount of dye released from the adsorbent until an equilibrium is reached. The dye cannot be released completely. Therefore, there are still some dye which strongly bonded to the adsorbent. It is clear that the contact time of $240 \mathrm{~min}$ gave the highest desorption efficiency of $97.07 \%$.

\section{Effect of Temperature of Desorption}

The effect of temperature on the desorption process is illustrated in Fig. 4. The Desorption used ethanol as a solvent, $\mathrm{pH}$ solution 6.3 and contact time of $240 \mathrm{~min}$. The temperature of desorption was set up at $30,45,60$, and $75{ }^{\circ} \mathrm{C}$. The figure indicated that optimum temperature for desorption of procion red MX$5 \mathrm{~B}$ dye from alumina-activated carbon composite is 45 ${ }^{\circ} \mathrm{C}$ with desorption efficiency of $98.56 \%$ and decreased at 60 and $75{ }^{\circ} \mathrm{C}$. The decreasing of desorption is caused by evaporation of ethanol, hence reduce its ability to dissolve dyes from alumina-activated carbon composite.

Ethanol has a boiling point at $78.37{ }^{\circ} \mathrm{C}$. The composition of ethanol and water in a solvent influences the boiling point. Each dye compounds had different optimum temperature of desorption, i.e. methylene blue was desorbed optimally by ethanol at $25{ }^{\circ} \mathrm{C}$ [28], reactive blue BF-5G through optimal desorption at $30{ }^{\circ} \mathrm{C}$ using isopropyl alcohol [11], reactive red gave optimum desorption from carbon nanotubes at $48^{\circ} \mathrm{C}$ using $\mathrm{NaOH}$ [6], the yellow and red dyes were desorbed optimally from activated carbon using alcohol $20 \%$ at 40 and $50{ }^{\circ} \mathrm{C}$ [12]. 


\section{Kinetic of Desorption}

The kinetic study is provided information mechanism on the adsorption process. Kinetic desorption In the present study expressed by a pseudofirst order rate equation as represented as eq. $3[12,26]$.

$\frac{\mathrm{q}_{\mathrm{t}}}{\mathrm{q}_{0}}=\exp \left(-\mathrm{k}_{\text {des }} \mathrm{t}\right)$

where $\mathrm{q}_{\mathrm{t}}$ and $\mathrm{q}_{0}$ are the concentration of procion red $\mathrm{MX}$ 5B dye in the composite $(\mathrm{mg} / \mathrm{g})$ at time $t$ and the initial total procion red MX-5B dye in the composite $(\mathrm{mg} / \mathrm{g})$. $k_{\text {des }}$ is a rate constant $\left(\mathrm{min}^{-1}\right)$ of pseudo first order desorption. The linear form of the pseudo first order kinetic desorption as given in eq. 4 [26].

$\ln \frac{q_{t}}{q_{0}}=\ln \theta-k_{\text {des }} t+(1-\theta)$

with $\theta$ as the value of desorbable fraction. Plot of $\ln q_{t} / q_{0}$ and $t$ are used calculated of $k_{\text {des }}$ and $\theta$. The pseudo first order kinetic desorption of procion red MX-5B dye using ethanol is represented in Fig. 5.

The kinetic study of desorption of procion red MX5B dye was fitted to the pseudo first-order with the highest $R^{2}$ value of 0.9855 . The value of kdes and $\theta$ are 6.56.10-2 $\mathrm{min}^{-1}$ and 1.152, respectively. Desorption process is influenced by the strong interaction between adsorbent and dye molecules, such as van der Waals forces or electrostatic attraction. The adsorption is indicated as chemisorption process if the desorption is irreversible [11].

\section{Composite Morphology Before and After Desorption}

Fig. 6 (a) and (b) display characterization result of alumina-activated carbon composite using SEM with 10,000x magnification. The morphology shows that the surface of alumina-activated carbon composite before desorption is denser and heterogeneous compared to after desorption. It indicates the surface of aluminaactivated carbon composite become saturated by adsorbing procion red MX-5B dyes.
Formation of pore in the surface of aluminaactivated carbon composite after desorption process confirmed that procion red MX-5B dye was successfully removed. EDX analysis of alumina-activated carbon composite was conducted to determine atomic composition contained within adsorbent which presented in Table 2. The decreased of Al content in the composite after desorption process is obvious along with $\mathrm{O}$ content. It appeared that alumina was also partly removed through desorption process as well as the procion red MX-5B dye.

FTIR spectra of alumina-activated carbon composite before and after desorption are shown on Fig. 7. The wavenumber in range of $557.0-748.3 \mathrm{~cm}^{-1}$ indicates $\mathrm{Al}-\mathrm{O}$ bond [29]. This FTIR spectra of composite before desorption investigated at $592.1 \mathrm{~cm}^{-1}$, whereas after desorption appears at $590.2 \mathrm{~cm}^{-1}$.

Table 2. Elemental data of alumina-activated carbon composite before and after desorption

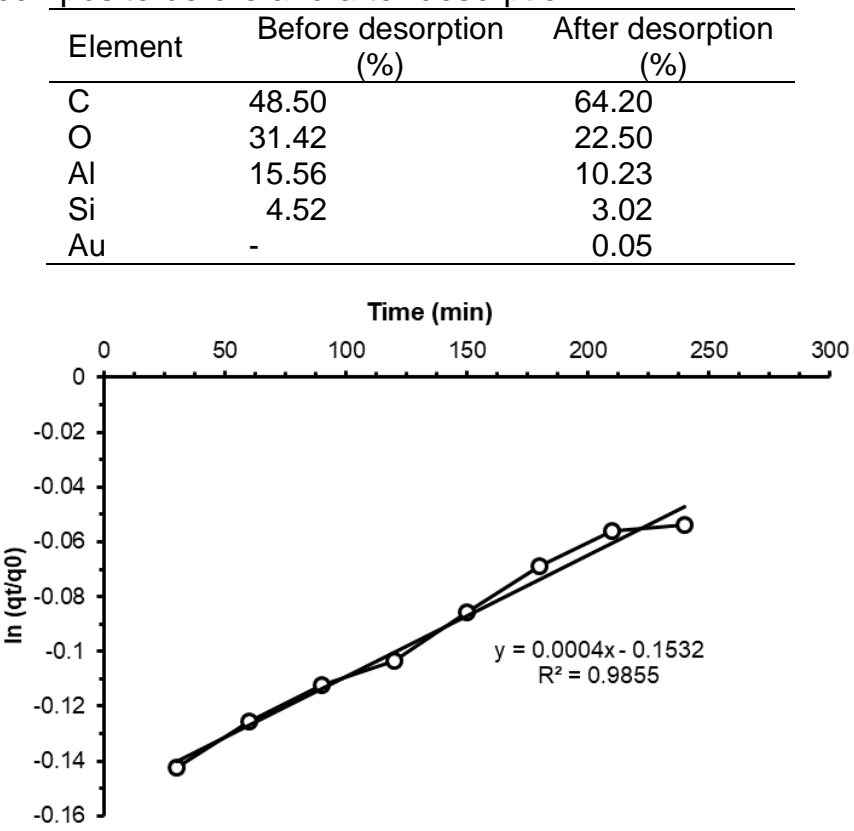

Fig 5. Pseudo first-order desorption kinetic
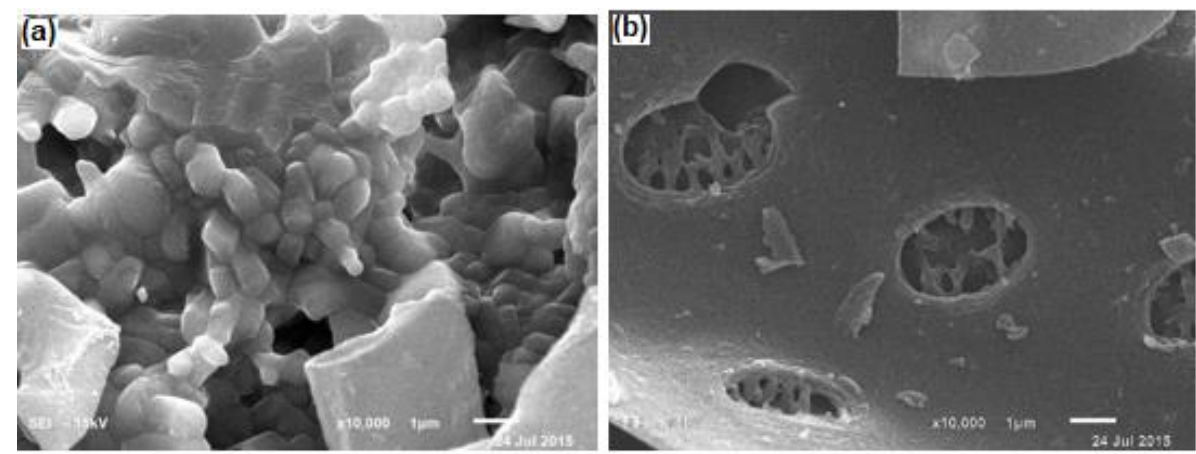

Fig 6. Morphology of alumina-activated carbon composite before desorption (a) and after desorption (b) 


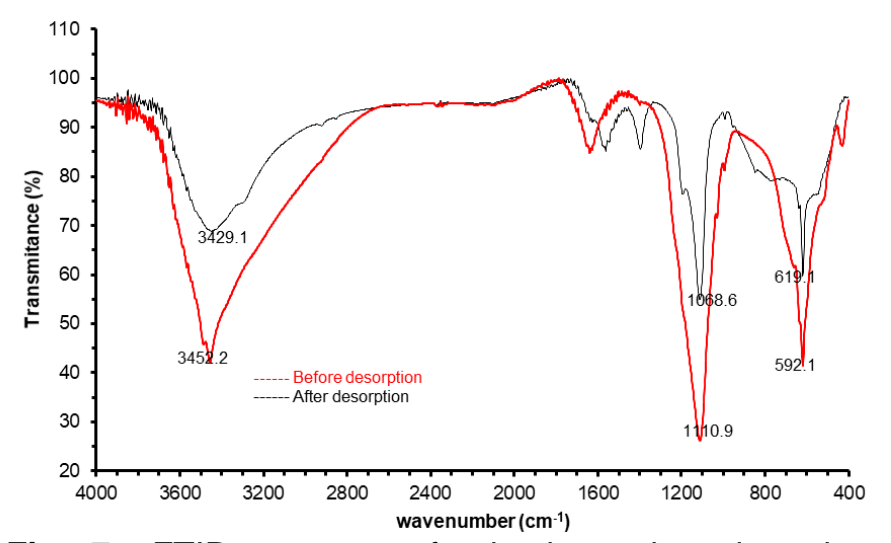

Fig 7. FTIR spectra of alumina-activated carbon composite before and after desorption

Table 3. Adsorption capacity of alumina-activated carbon composite after desorption process

\begin{tabular}{ccc}
\hline cycle & $\begin{array}{c}\text { Adsorption } \\
\text { capacity }(\mathrm{mg} / \mathrm{g})\end{array}$ & $\begin{array}{c}\text { Desorption efficiency } \\
(\%)\end{array}$ \\
\hline 1 & 12.38 & 98.56 \\
2 & 8.17 & 85.23 \\
3 & 7.38 & 73.46 \\
\hline
\end{tabular}

A sharp peak at 1110.9 and $1066.6 \mathrm{~cm}^{-1}$ indicated the $\mathrm{C}-\mathrm{O}$ bond of alumina-activated carbon composite before and after desorption, respectively. Peaks at 3452.2 and $3429.1 \mathrm{~cm}^{-1}$ are assigned for $\mathrm{H}-\mathrm{O}-\mathrm{H}$ stretching. Generally, the FTIR spectra of the composite before and after desorption reveals the same pattern of wavenumber. Change in intensity of composite may be related to the desorption process [11]. According to the data, we can conclude that there is no structural change of composite due to desorption process.

\section{Re-Adsorption Process of Procion Red MX-5B Using Alumina-Activated Carbon Composite}

Alumina-activated carbon composite was re-used to adsorb red procion MX-5B dye in the same process of adsorption [19]. Desorption was conducted after adsorption using ethanol $70 \%$ at $45^{\circ} \mathrm{C}$ for $240 \mathrm{~min}$. The adsorption-desorption process was carried out for three cycles and calculated of composite adsorption capacity and desorption efficiency are shown in Table 3.

The repeated desorption process on the composite decreased the adsorption capacity of alumina-activated carbon composite. The decrease of adsorption capacity is depending on the functional groups in the adsorbent. Several dyes cannot be separated from the adsorbent, therefore block the pore of adsorbent [30]. From the EDX analysis, the amount of alumina is reduced after the desorption process, so the active sites in the composite are also reduced. The occupied of activated carbon surface sites by solvent molecules leading to the decreasing of adsorption capacity [9].

\section{CONCLUSION}

The alumina-activated carbon can be used as an adsorbent to remove procion red $M X-5 B$ dye in solution. The procion red $\mathrm{MX}-5 \mathrm{~B}$ dye can be released from adsorbent and the adsorbent can be re-used for adsorption. In this study, the effective solvent for desorption of procion red $\mathrm{MX}-5 \mathrm{~B}$ dye from aluminaactivated carbon was ethanol. The highest desorption efficiency was obtained at $45{ }^{\circ} \mathrm{C}$ for $240 \mathrm{~min}$. The desorption kinetic model followed the pseudo firstorder. The desorption efficiency of alumina-activated carbon after three cycles of desorption and re-used for adsorption process decreased as calculated from 98.56 to $73.46 \%$. Thus the alumina-activated carbon composite can be promising as an adsorbent to remove the pollutants, especially dyes.

\section{ACKNOWLEDGEMENT}

The author is very grateful to the Ministry of Research Technology and Higher Education (KEMENRISTEK DIKTI) for providing funding via Fundamental research grant year 2016. The author also would like to thank to Sriwijaya University for the support to completing this research.

\section{REFERENCES}

[1] Alimohammadi, Z., Younessi, H., and Bahramifar, N., 2016, Desorption reactive red 198 from activated carbon prepared from walnut shells: Effects of temperature, sodium carbonate concentration and organic solvent dose, $A d v$. Environ. Technol., 3, 137-141.

[2] So, C.M., Cheng, M.Y., Yu, J.C., and Wong, P.K., 2002, Degradation of azo dye procion red MX-5B by photocatalytic oxidation, Chemosphere, 46 (6), 905-912.

[3] Zaharia, C., Suteu, D., Muresan, A., and Popescu, A., 2009, Textile wastewater treatment by homogenous oxidation with hydrogen peroxide, Environ. Eng. Manage. J., 8 (6), 1359-1369.

[4] Calvete, T., Lima, E.C., Cardoso, N.F., Dias, S.L.P., and Pavan, F.A., 2009, Application of carbon adsorbents prepared from the Brazilian pine-fruit-shell for the removal of procion red $M X$ 3B from aqueous solution-kinetic, equilibrium, and thermodynamic studies, Chem. Eng. J., 155 (3), 627-636.

[5] Moreira, R.F.P.M., Peruch, M.G., and Kuhnen, N.C., 1998, Adsorption of textile dyes on alumina, 
equilibrium studies and contact time effects, Braz. J. Chem. Eng., 15 (1), 1-8.

[6] Kuo, C.Y., 2008, Desorption and re-adsorption of carbon nanotubes: comparisons of sodium hydroxide and microwave irradiation processes, J. Hazard. Mater., 152 (3), 949-954.

[7] Sahbaz, D.A., Yakar, A., and Gündüz, U., 2015, Investigation of desorption kinetics and equilibrium of an anionic dye from magnetic anion adsorbents, Proceedings of the $14^{\text {th }}$ International Conference on Environmental Science and Technology, 564, 1-5.

[8] Li, J., Feng, J., and Yan, W., 2013, Excellent adsorption and desorption characteristics of polypyrrole/ $\mathrm{TiO}_{2}$ composite for methylene blue, Appl. Surf. Sci., 279, 400-408.

[9] Lu, P.J., Lin, H.C., Yu, W.T., and Chem, J.M., 2011, Chemical regeneration of activated carbon used for dye adsorption, J. Taiwan Inst. Chem. Eng., 42 (2), 305-311.

[10] van Deventer, J.S.J., and Merwe, P.F.P.D., 1992, Effect of the temperature on the desorption of gold cyanide from activated carbon, Thermochim. Acta, 221 (1), 99-113.

[11] Carvalho, D.S., Fagnani, H.M.C., Junior, O.M.C., Barros, M.A.S.D., and Arroyo, P.A., 2014, Influence of initial water $\mathrm{pH}$ and concentration of regenerating agent on the dye desorption efficiency of bone char, $X$ Encontro Brasileiro Sobre Adsorção (EBA 10), 27-30 April 2014, Guaruja S-P.

[12] Chern, J.M., and Wu, C.Y., 2001, Desorption of dye from activated carbon beds: Effects of temperature, $\mathrm{pH}$, and alcohol, Water Res., 35 (17), 4159-4165.

[13] Luo, H., Zhang, S., Li, X., Xu, Q., Liu, J., and Wang, Z., 2017, A facile route for preparation of magnetic biomass activated carbon with high performance for removal of dye pollutants, Environ. Sci. Pollut. Res. Int., 24 (18), 15599-15608.

[14] Chartterjee, M., Naskar, M.K., and Ganguli, D., 2003, Sol-emulsion-gel synthesis of alumina zirconia composite microsphere, J. Sol-Gel Sci. Technol., 28 (2), 217-225.

[15] Benerjee, S., Dubey, S., Gautam, R.K., Chattopadhayaya, M.C., and Sharma, Y.C., 2017, Adsorption characteristics of alumina nanoparticles for the removal of hazardous dye, orange $G$ from aqueous solutions, Arabian J. Chem., In Press, 116.

[16] Bhargavi, R.J., Maheshwari, U., and Gupta, S., 2015, Synthesis and use of alumina nanoparticles as an adsorbent for the removal of $\mathrm{Zn}$ (II) and CBG dye from wastewater, Int. J. Ind. Chem., 6 (1), 3141.

[17] Osalo, T.P., Merufinia, E., and Saatlo, M.E., 2013, Phosphorus removal from aqueous solutions by bentonite: Effect of $\mathrm{Al}_{2} \mathrm{O}_{3}$ addition, J. Civ. Eng. Urban., 3 (5), 317-322.

[18] Darjito, D., Purwonugroho, D., and Nisa, S.N., 2006, Study on adsorption of $\mathrm{Cd}$ (II) by chitosanalumina, Indones. J. Chem., 6 (3), 238-244.

[19] Hariani, P.L., Fatma, and Zulfikar, 2015, Aluminaactivated carbon composite as adsorbent of procion red dye from wastewater songket industry, J. Pure Appl. Chem. Res., 4 (1), 25-33.

[20] Raut, P.A., Dutta, M., Sengupta, S., and Basu, J.K., 2013, Alumina-carbon composite as an effective adsorbent for removal of methylene blue and alizarin red-s from aqueous solution, Indian $\mathrm{J}$. Chem. Technol., 20, 15-20.

[21] Dong, L., Zhu, Z., Qiu, Y., and Zhao, J., 2010, Removal of lead from aqueous solution by hydroxyapatite/magnetite composite adsorbent, Chem. Eng. J., 165 (3), 827-834.

[22] Chu, K.H., and Hashim, M.A., 2001, Desorption of copper from polyvinyl alcohol-immobilized seaweed biomass, Acta Biotechnol., 21 (4), 295306.

[23] Berez, A., Ayari, F., Abidi, N., Schäfer, G., and Trabelsi-Ayadi, M., 2014, Adsorption-desorption processes of azo dye on natural bentonite: batch experiments and modeling, Clay Miner., 49 (5), 747-763.

[24] Solace-Ríos, M.J., Villalva-Coyote, R., and DíazNava, M.C., 2010, Sorption and desorption of remazol yellow by a Fe-zeolitic tuff, J. Mex. Chem. Soc., 54 (1), 59-68.

[25] Kosmulski, M., 2009, pH-dependent surface charging and points of zero charge. IV. Update and new approach, J. Colloid Interface Sci., 337 (2), 439-448.

[26] Wakansi, D., Horsfall, M., and Spiff, A.I., 2005, Desorption of $\mathrm{Pb}^{2+}$ and $\mathrm{Cu}^{2+}$ from Nipa palm (Nypa fruticans Wurmb) biomass, Afr. J. Biotechnol., 4 (9), 923-927.

[27] Zhu, M., Meng, D., Wang, C., Di, J., and Diao, G., 2013, Degradation of methylene blue with $\mathrm{H}_{2} \mathrm{O}_{2}$ over a cupric oxide nanosheet catalyst, Chin. J. Catal., 34 (11), 2125-2129.

[28] Ozdemir, C.S., 2012, Adsorption and desorption kinetics behavior of methylene blue onto activated carbon, Physicochem. Prob. Miner. Process., 48 (2), 441-454.

[29] Saikia, B.J., and Parthasarathy, G., 2010, Fourier transform infrared spectroscopic characterization of kaolinite from Assam and Meghalaya, Northeastern India, J. Mod. Phys., 1 (4), 206-210.

[30] Filipkowska, U., and Rodziewicz, J., 2011, Cyclic sorption and desorption of reactive dyes onto chitosan beads, Prog. Chem. Appl. Chitin, 16, 7378. 